\title{
MACROSTRUCTURE AND DENSITY OF PINE AND SPRUCE WOOD ON FALLOW LANDS ON NORTH-WEST OF RUSSIA
}

\author{
Dmitry Danilov ${ }^{1,2}$, Sergey Janusz ${ }^{1}$ \\ ${ }^{1}$ Leningrad Scientific Research Institute of Agriculture 'BELOGORKA', Russia \\ ${ }^{2}$ Saint-Petersburg State Forest Technical University named after S.M. Kirov, Russia \\ stown200@mail.ru
}

\begin{abstract}
Growing spruce and pine wood on land being out of active agricultural use is important for many European regions. The study of the qualitative characteristics of coniferous wood makes it possible to predict target indicators of the obtained raw materials. The influence of xylem structural elements on the density of spruce pine wood on the postagrogenic lands of the boreal zone of Russia was studied. The objects of the research were spruce-pine stands growing on old arable land in the Gatchina district of the Leningrad region. Depending on the share of the species, various anatomical indicators of the macro-structure of wood influence the formation of the spruce and pine wood density. For the spruce part of the forest stand, the width of the annual increase makes a greater contribution to the formation of indicators of wood density. For the pine part of the forest stand, the density of the wood correlates with the proportion of late xylem. With a different proportion of the species, the influence of macro-structural elements on the density of wood changes. Conducted analysis of variance showed a significant effect of the forest stand composition on the anatomical macro-structure of spruce and pinewood.
\end{abstract}

Key words: pine, spruce, density of wood, anatomical macro-structure.

\section{Introduction}

The reduction of agricultural land in the last decade of the late XX century and the first decade of the $\mathrm{XXI}$ century is global. The problem of abandonment is manifested in the small and large agricultural sectors of Europe, the countries of South and North America, Australia, and countries of Asia, and it has been growing since the 1950s. More than fifty percent of the land is abandoned for reasons resembling the Russian ones: environmental, socio-economic, ideological, infrastructural, related to the transition of extensive agriculture to intensive one (Allen et al., 2005; Chenghua \& Heping, 1992; Lyury, Goryachkin, \& Karavaeva, 2010; Von Braun \& Mirzabaev, 2016; Ramankutty \& Foley, 1992).

Over the period of 1961-1987, according to the FAO, the area of agricultural land in Western Europe decreased by $11.4 \%$ of the world agricultural land and amounted to 25.1 million ha. Therefore, the problem of using land left out of agricultural use is relevant for European countries. In Russia, the main deposits body ( $45 \%$ of their total area) is located in the southern taiga subzone, where they represent about $20 \%$ of the territory (Romanenko, 2008).

The experience of growing coniferous tree plantations on post-agrogenic lands shows that such forest stands in terms of their reserve and productivity are superior to those planted on forestlands in many regions of Europe (Ruskule et al., 2012; Zeidler, Vlastimil, \&Schenfelder, 2018).The results of the research suggest that on former arable lands in North-West Russia, the joint cultivation of pine and spruce should be considered as a biologically justified silvicultural activity. On post-agrogenic lands trees show accelerated growth, which can lead to a decrease in the quality of wood. Earlier studies on this issue in various European countries show that, depending on the region of studies, the formation of spruce and pine wood density at the anatomical level can be influenced by various factors (Daugaviete et al., 2015; Bartoš, Souček, \& Kacblek, 2010; Tomczak \& Jelonek, 2013). Various authors have established trends in the density (physical and mechanical properties) of pine and spruce wood relative to growing conditions (Zeltiņš et al., 2018). Studies have shown that the radial growth of pine and spruce on the deposits is much higher than on forestlands (Golubeva, 2015; Lohov, 2011). A relatively rapid increase leads to an increase in the width of the annual ring and, consequently, to a change in the density of the wood. The basic density of pinewood on the fallow lands of the Arkhangelsk region is $10 \%$ lower than the average values for the study region. The increased density of spruce wood growing on old arable land is associated with a high percentage of late wood, which is more than average for the species. However, in contrast to the density of pine wood grown on fallow lands and having values below the average ones for the middle taiga subzone, spruce wood reaches a density of 60 years old and is close to the standard value. As for spruce and pine plantations of artificial and natural origin growing on the post-agrogenic lands in the Leningrad and Pskov regions, there is a high density of wood, however, the formation of wood density was influenced by various xylem structural elements (Danilov et al., 2016; Janusz $\&$ Danilov, 2018). The qualitative and quantitative indicators of pine and spruce wood growing on postagrogenic lands in the conditions of the North-West of Russia are not lower than the average indicators for the region. The data on the basic density of 


\section{The basic density of pine (Pinus sylvestris) and spruce (Picea abies) wood in the post-agrogenic lands of North-West Russia}

\begin{tabular}{|c|c|c|c|c|c|}
\hline \multirow{2}{*}{ Area } & \multirow{2}{*}{ Species } & \multirow{2}{*}{ Age, years } & \multirow{2}{*}{$\begin{array}{l}\text { Base wood density, } \\
\qquad \mathrm{kg} \mathrm{m}^{-3}\end{array}$} & \multicolumn{2}{|c|}{$\begin{array}{c}\text { Wood share, } \\
\%\end{array}$} \\
\hline & & & & Early & Late \\
\hline \multirow[t]{6}{*}{ Leningrad region* } & Spruce, forest crops & 110 & 383 & 60 & 40 \\
\hline & Pine, forest crops & 110 & 420 & 55 & 45 \\
\hline & Spruce, plantation crops & 40 & 402 & 70 & 30 \\
\hline & Pine, plantation crops & 40 & 422 & 65 & 35 \\
\hline & Spruce, natural plantations & 120 & 460 & 55 & 45 \\
\hline & Pine, natural plantations & 120 & 480 & 60 & 40 \\
\hline \multirow[t]{2}{*}{ Pskov region* } & Spruce, plantation crops & 40 & 380 & 65 & 35 \\
\hline & Pine, plantation crops & 40 & 360 & 60 & 40 \\
\hline \multirow{2}{*}{$\begin{array}{l}\text { Vologodskaya } \\
\text { Oblast** }\end{array}$} & Pine, forest crops & 55 & 360 & 73 & 27 \\
\hline & Pine, natural plantations & 55 & 360 & 75 & 25 \\
\hline \multirow{2}{*}{$\begin{array}{l}\text { Arkhangelsk } \\
\text { region*** }\end{array}$} & Pine, natural plantations & 65 & 400 & 55 & 45 \\
\hline & Spruce, natural plantations & 60 & 388 & 67 & 33 \\
\hline
\end{tabular}

According to * Danilov, 2016;** Lokhov, 2011; *** Golubeva, 2015.

wood in plantations on post-agrogenic lands in the Northwestern region given below show that in most cases the density of wood in pine and spruce is higher than the average indicators for the study region, which are: for spruce $370-380 \mathrm{~kg}$ per $\mathrm{m}^{3}$, and for pine $400-410 \mathrm{~kg}$ per $\mathrm{m}^{3}$. It should be noted that, depending on age and origin, the proportion of late and early wood in pine and spruce correlate differently in the annual growth and, therefore, affects the density of wood of these species.

Therefore, the task of our study was to reveal the influence of the xylem structural elements of pine and spruce on the density of their wood, as well as, to assess the contribution of the zone of early and late wood, and the width of the annual increment to the formation of the density of pine and spruce wood growing on post-agrogenic lands.

\section{Materials and Methods}

We have investigated four sites in the former arable lands with a stand of mixed trees of spruce and pine up to 80-85 years of age. The subjects of the research are located in the south-west of the Leningrad Region in the Gatchina District (Table 1). The soil represents a degraded agrozem covered with a humus horizon layer with presence of podsol $10-12 \mathrm{~cm}$ in thickness formed during formation of forest community. The underlying bed is a double-layer one, consisting of a red-colored moraine loam covered with a sandy loam horizon. The growing conditions of the region under investigation correspond to the I-Ia growth class.

To determine the parameters of the macrostructure and the physical properties of pine and spruce wood, cores were used that were obtained using an age drill at a height of $1.3 \mathrm{~m}$ from the root crown of $15-20$ medium trees of the forest stand.. The age of the coniferous and deciduous species was determined by selected cores at the level of the root of the neck with the calculation of annual rings. Determination of wood basic density was performed according to recommendations of O.I. Poluboyarinova (1976) using the method of maximum moisture content of samples (Table 2). To study the elements of wood macrostructure in samples in the form of cores, the method of processing samples with a high resolution scanner was used, which, according to modern research, gives results with a measurement accuracy interval of $\pm 0.01 \mathrm{~mm}$. The prepared wood sample, ground smooth and glued to the holder, was placed on a high resolution scanner, and the sample surface was scanned with an accuracy of 1200 dpi in full color mode (16.7 million colors). The digitized scanned image was adjusted subsequently in terms of brightness and contrast indicators to better distinguish early and late core wood. To measure the indicators of the wood macrostructure in the obtained image, the application 'Geo-information system Panorama 10' was used. The image was converted to a geographic information system with a resolution similar to the scanning resolution (conventionally, $1 \mathrm{~m}$ on an electronic map was taken as $1 \mathrm{~mm}$ ). GIS tools were used to draw a line along the longitudinal axis of the core. For each annual increment, the boundaries of the zone of the late and early zones of wood were established and points were set on the line at the appropriate places. Thus, as indicators characterizing the macrostructure of wood, we measured the average width of the annual layers and the content of the late and early xylem in the annual layer during the life 
Taxation characteristics of pine and spruce stands on postagrogenic lands

\begin{tabular}{|c|c|c|c|c|c|c|c|}
\hline \multicolumn{8}{|c|}{ Research object \#1 } \\
\hline Species & Composition, $\%$ & A, years & $\mathrm{D}_{\mathrm{av}}, \mathrm{cm}$ & $\mathrm{H}_{\mathrm{av}}, \mathrm{m}$ & $\mathrm{G}, \mathrm{m}^{2}$ & $\mathrm{~N} \mathrm{ha}^{-1}$ & $\mathrm{M}, \mathrm{m}^{3}$ \\
\hline Spruce & 87 & 80 & 32.5 & 30.2 & 31.5 & 380 & 431 \\
\hline Pine & 11 & 85 & 35.7 & 27.9 & 4.9 & 50 & 55 \\
\hline Aspen & 0.5 & 50 & 17.4 & 21.7 & 0.2 & 7 & 2 \\
\hline Birch & 1.5 & 60 & 19.4 & 22 & 1 & 33 & 9 \\
\hline Total: & & & 32.6 & 30 & 37.5 & 470 & 497 \\
\hline \multicolumn{8}{|c|}{ Research object \#2 } \\
\hline Spruce & 55 & 80 & 27.1 & 28.2 & 23.3 & 405 & 309 \\
\hline Pine & 38 & 85 & 35.2 & 27.8 & 18.9 & 197 & 215 \\
\hline Aspen & 5 & 50 & 29.3 & 25.7 & 2.3 & 34 & 27 \\
\hline Birch & 2 & 60 & 18.0 & 21.6 & 1.4 & 54 & 14 \\
\hline Total: & & & 30.1 & 28.0 & 45.9 & 690 & 565 \\
\hline
\end{tabular}

Basic density of spruce and pine wood at the research objects $\left(\mathrm{kg} \mathrm{m}^{-3}\right)$

Table 2

\begin{tabular}{|c|c|c|c|c|c|c|c|c|c|c|}
\hline $\begin{array}{c}\text { Diameter class, } \\
\mathrm{cm}\end{array}$ & 12 & 16 & 20 & 24 & 28 & 32 & 36 & 40 & 44 & 48 \\
\hline \multicolumn{11}{|c|}{ Research object \#1 } \\
\hline \multirow[t]{2}{*}{ Spruce } & 412 & 397 & 406 & 360 & 356 & 382 & 389 & 436 & 366 & 412 \\
\hline & 448 & 446 & 383 & 356 & 385 & 373 & 360 & 418 & 341 & 448 \\
\hline \multirow[t]{2}{*}{ Pine } & - & - & 376 & 384 & 413 & 419 & 392 & 387 & 376 & 379 \\
\hline & - & - & - & - & 373 & 393 & 374 & 381 & 367 & 387 \\
\hline \multicolumn{11}{|c|}{ Research object \#2 } \\
\hline \multirow[t]{2}{*}{ Spruce } & 406 & 462 & 445 & 383 & 408 & 437 & 427 & - & - & - \\
\hline & 564 & 407 & 435 & 390 & 449 & 459 & - & - & - & - \\
\hline \multirow[t]{2}{*}{ Pine } & - & - & - & 396 & 348 & 404 & 367 & 377 & 374 & 323 \\
\hline & - & - & - & 360 & 381 & 370 & 351 & 380 & 396 & 377 \\
\hline
\end{tabular}

of the tree. These indicators were determined for all wood samples taken from model trees in the study plots. Later, the Microsoft Excel spreadsheet processor was used to systematize the obtained quantitative and qualitative data on the macrostructure of pine and spruce wood.

The collected field materials were processed by variation statistics methods; the processing of the obtained qualitative and quantitative data was carried out using the following software: Statistica 10, STATGRAPHICS Centurion XVI, and Microsoft Excel. Correlation and ANOVA analysis of the obtained data were used.

\section{Results and Discussion}

Depending on the fraction representation (\%) classes of trunk diameter $(\mathrm{cm})$ spruce and pine stands observed at different ratio share the late and early wood growth ring of wood (Figures 1-2). In the forest stand at the experimental object (1) with a predominance of spruce, there is a tendency to decrease in the proportion of late wood in the annual rings. In the stand with less spruce participation, this trend is not observed. For pine stands, there is a slight decrease in the share of late wood in annual rings towards large classes of trunk diameter at experimental sites.

The obtained data on the proportion of late and early wood in spruce and pine trees in thickness values at the study plots show different quantitative ratios in these stands. With a larger share of spruce in the composition of plantations in the macrostructure of annual growth, a greater percentage of early wood is observed than in the forest stand with lower participation thereof. The same trend is observed for the pine part of the stand. Apparently, an increase in the proportion of the species in the composition of the forest stands affects the increase in the growth of early wood. It should be noted that there is a large variability in the ratio of the proportion of late and early wood along the tree thickness values in the spruce element of plantations.

Conducted correlation analysis of data on the correlation of macro-structural elements and the density of spruce and pinewood showed a different correlation ratio between these indicators in plantations 

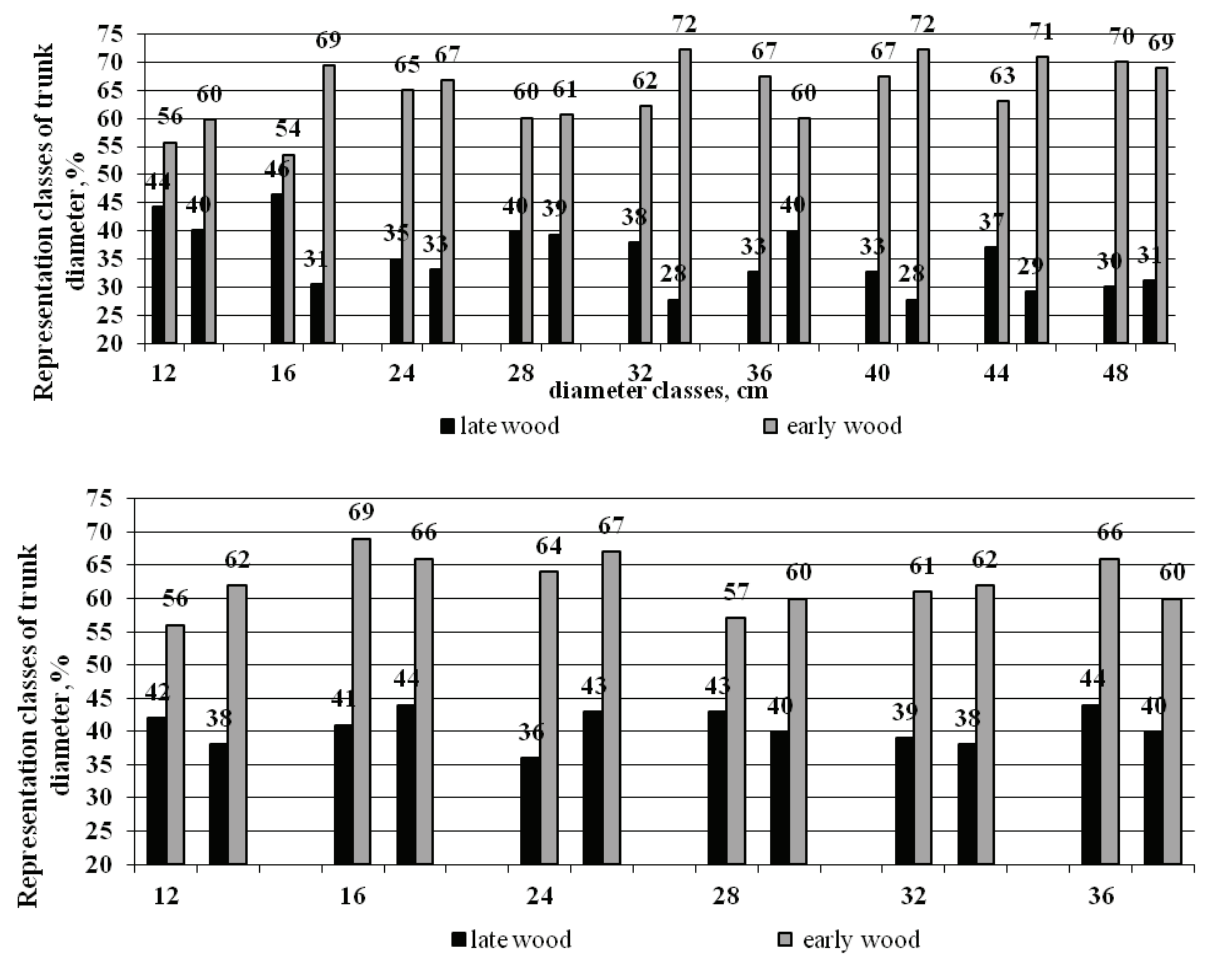

Figure 1. Spruce sample plot \#1 \& plot \#2.
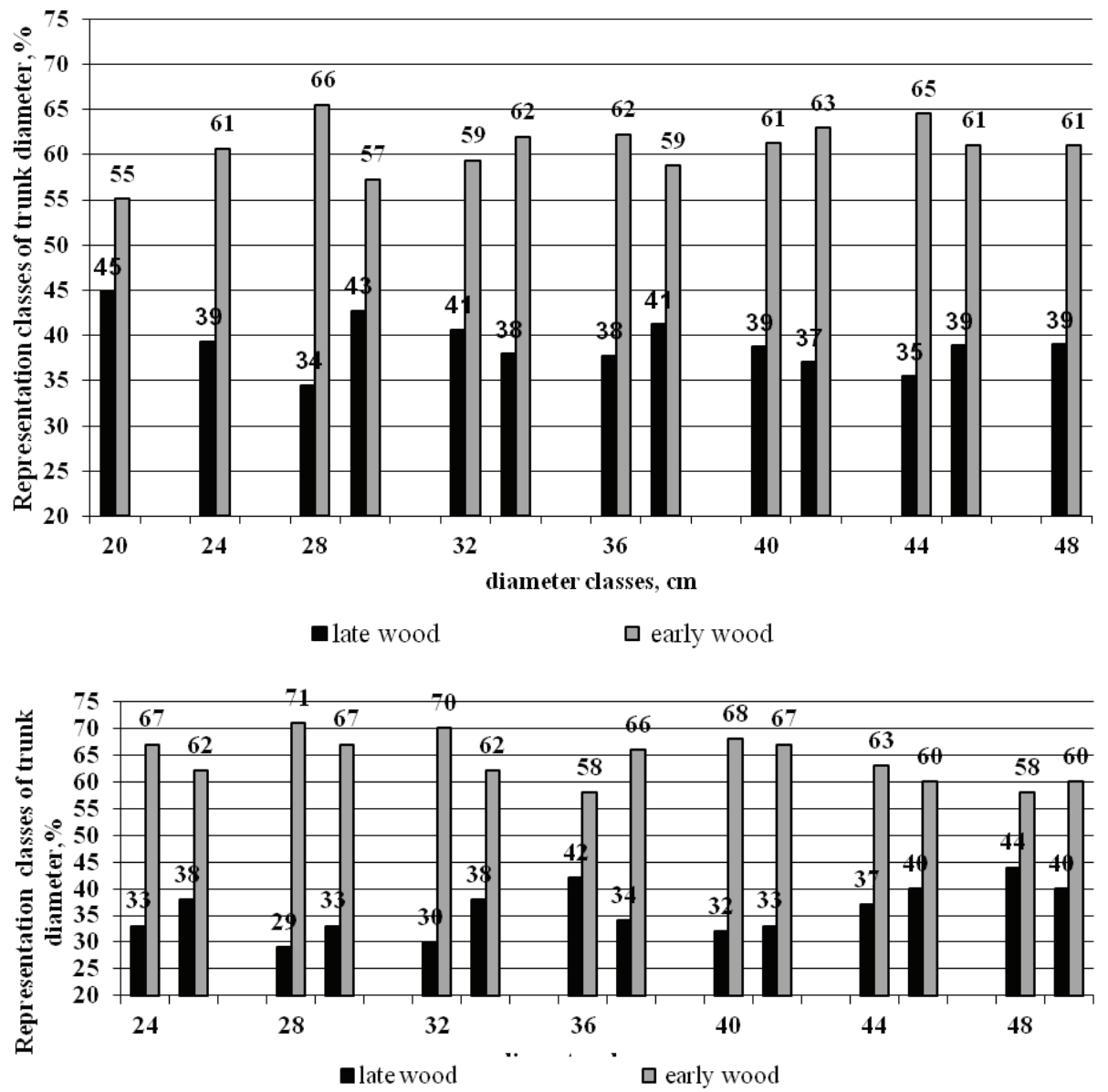

Figure 2. Pine sample plot \#1 \& plot \#2. 


\section{Rank analysis of correlation of macrostructure and density of spruce-tree and pine-tree wood} in the mixed forests (by Spearman's criterion)

\begin{tabular}{|c|c|c|c|c|c|c|}
\hline \multirow{2}{*}{$\begin{array}{c}\text { Pair of } \\
\text { Variables }\end{array}$} & \multicolumn{3}{|c|}{$80 \%$ - spruce-tree in the composition } & \multicolumn{3}{|c|}{$58 \%$ - spruce-tree in the composition } \\
\hline & Valid N & Spear-man R & p-value & Valid N & Spear-man R & p-value \\
\hline $\begin{array}{l}\text { late wood zone \& } \\
\text { basic wood density }\end{array}$ & \multirow{3}{*}{40} & 0.410 & $<0.05$ & \multirow{3}{*}{26} & 0.513 & $<0.05$ \\
\hline $\begin{array}{l}\text { early wood zone \& } \\
\text { basic wood density }\end{array}$ & & -0.251 & $<0.05$ & & -0.201 & $<0.05$ \\
\hline $\begin{array}{l}\text { annual ring width \& } \\
\text { basic wood density }\end{array}$ & & 0.762 & $<0.05$ & & 0.654 & $<0.05$ \\
\hline \multicolumn{4}{|c|}{$18 \%-$ pine-tree in the composition } & \multicolumn{3}{|c|}{$38 \%-$ pine-tree in the composition } \\
\hline $\begin{array}{l}\text { late wood zone \& } \\
\text { basic wood density }\end{array}$ & \multirow{3}{*}{28} & 0.772 & $<0.05$ & \multirow{3}{*}{28} & 0.842 & $<0.05$ \\
\hline $\begin{array}{l}\text { early wood zone \& } \\
\text { basic wood density }\end{array}$ & & -0.183 & $<0.05$ & & -0.234 & $<0.05$ \\
\hline $\begin{array}{l}\text { annual ring width \& } \\
\text { basic wood density }\end{array}$ & & 0.524 & $<0.05$ & & 0.451 & $<0.05$ \\
\hline
\end{tabular}

Conducted analysis of variance of the data showed a significant difference in the xylem structural elements depending on the share of the species in the plantation (Table 4).

Table 4

Dispersion analysis of the significance of differences in the indicators of the spruce and pine wood macrostructure on experimental objects

\begin{tabular}{|c|c|c|c|c|c|c|c|c|}
\hline Variables & $\begin{array}{c}\text { Av.sq. } \\
\text { deviation }\end{array}$ & $\begin{array}{c}\text { Sum.sq. } \\
\text { deviation }\end{array}$ & $\begin{array}{c}\text { St.tr. } \\
\text { deviation }\end{array}$ & \multicolumn{1}{c|}{$\begin{array}{c}\text { Av.sq. } \\
\text { deviation }\end{array}$} & $F_{\text {estim }}$ & $F_{\text {table }}$ & Value $p$ \\
\hline \multicolumn{7}{|c|}{ Pine $18 \%$ and $38 \%$} \\
\hline Late wood & 0.00031 & 280.914 & 3407 & 0.08245 & 10,4 & 5.2 & $<0.05$ \\
\hline Early wood & 1.08542 & 2644.476 & 3407 & 0.77619 & 17.7 & 5.2 & $<0.05$ \\
\hline Annual ring width & 1.04910 & 4243.677 & 3407 & 1.24558 & 17.1 & 5.2 & $<0.05$ \\
\hline \multicolumn{7}{|c|}{ Spruce $80 \%$ and $58 \%$} \\
\hline Late wood & 10.4830 & 214.326 & 5506 & 0.03893 & 269.3 & 5.1 & $<0.05$ \\
\hline Early wood & 101.3796 & 4157.009 & 5506 & 0.75500 & 134.3 & 5.1 & $<0.05$ \\
\hline Annual ring width & 177.0627 & 5570.784 & 5506 & 1.01177 & 175.1 & 5.1 & $<0.05$ \\
\hline
\end{tabular}

with different shares of these species (Table 3). On the experimental object with a predominance of spruce, a closer correlation was found between the density of wood and the width of the annual increment $\left(\mathrm{R}_{\mathrm{s}}=0.710\right)$. For the correlation between the density of spruce wood and the zones of late and early xylem, a moderate $\left(\mathrm{R}_{\mathrm{s}}=0.410\right)$ and weak correlation $\left(\mathrm{R}_{\mathrm{s}}=-0.251\right)$ was revealed. For the pine part of the forest stand, a bigger correlation was found between the density of wood and the zone of late xylem $\left(\mathrm{R}_{\mathrm{s}}=0.772\right)$ than with the width of the annual increment $\left(\mathrm{R}_{\mathrm{s}}=0.524\right)$. The density of pinewood correlates weakly with the zone of early xylem $\left(\mathrm{R}_{\mathrm{s}}=-0.183\right)$. In a tree stand with a larger share of pine participation, the correlation between structural elements and wood density is slightly different. For the spruce part of the forest stand, the correlation between the density of wood and the width of the annual growth is lower $\left(\mathrm{R}_{\mathrm{s}}=0.654\right)$, and with the proportion of late wood it is higher $\left(\mathrm{R}_{\mathrm{s}}=0.513\right)$ than in the forest stand with its larger participation. For the pine part of the forest stand, the density of wood correlates more strongly with the proportion of late xylem $\left(\mathrm{R}_{\mathrm{s}}=0.842\right)$ and less with the width of the annual increment $\left(\mathrm{R}_{\mathrm{s}}=0.451\right)$. The correlation between the density of wood and the zone of early xylem is higher $\left(\mathrm{R}_{\mathrm{s}}=-0.234\right)$ than in the forest stand with a lower participation of pine.

\section{Conclusions}

Based on the study, the following conclusions can be made:

1. On post-agrogenic lands, the density of spruce wood has a large correlation with the proportion of late xylem. 
2. In the pine part of the forest stand, the density of wood correlates more closely with the proportion of late xylem.

3. With an increase or decrease in the composition of the forest stand of spruce and pine, there is a change in the content of the proportion of early and late wood in the annual growth.
4. With the change in the share of the species in the composition of the stand, the correlation ratio between the density of wood and the xylem structural elements changes.

5. The composition of the stand has a significant effect on changes in the spruce and pine wood macrostructure on the post-agrogenic lands.

\section{References}

1. Allen, E.B., Cox, R.D., Tennant, T., Kee, S.N., \& Deutschman, D.H. (2005). Landscape restoration in southern California forblands: Response of abandoned farmland to invasive annual grass control. Journal of Plant Sciences. 53. 237-245.

2. Bai, Z.G., Dent, D.L., Olsson, L., \& Schaepman, M.E. (2008). Proxy global assessment of land degradation, Soil use and managemen, 24, (3), 223-234.

3. Bartoš, J., Souc`ek, J., \& Kacblek, D. (2010).Comparison of wood properties of 50-year-old spruce stands on sites experiencing different land use in the past. Rep. For. Res., 55, 195-200.

4. Von Braun, J., \& Mirzabaev, A. (2016). Land use change and economics of land degradation in the Baltic region, Balt. reg. 8, (3), 33-44.

5. Chenghua, Y., \& Heping, A. (1992). An evaluation of the initial stages of natural succession on abandoned land in mountain areas. Erosion, Debris Flows and Environment in Mountain Regions (Proceedings of the Chengdu Symposium, July 1992). IAHS Publ. No. 209, 465-469.

6. Danilov, D.A., Zhigunov, A.V., Krasnovidov, A.N., Ryabinin, B.N., Neverovsky, V.Yu., Shestakova, T.A., \& Anders, О.О. (2016). Выращивание древесных насаждений на постагрогенных землях (Growing of tree stands on post-agrogenic lands). Saint Petersburg: Publishing house of Polytechnic University, 130 p. (in Russian)

7. Daugaviete, M., Lazdina, D., Bambe, B., Bardule, A., Bardulis, A., \& Daugavietis, U. (2015). Productivity of different tree species in plantations and agricultural soils and related environmental impacts. Baltic Forestry 21(2), 349-358.

8. Golubeva, L.V. (2015). Лесоводственно-экологическая трансформация постагрогенных земель на карбонатных отложениях в подзоне средней тайги Архангельской области (Forest-ecological transformation of post-agrogenic lands on carbonate sediments in the sub-zone of the middle taiga of the Arkhangelsk region). Dissertation of the candidate of agricultural sciences. - Arkhangelsk: Northern (Arctic) Federal University named after MV Lomonosov, 160 p. (in Russian)

9. Janusz, S., \& Danilov, D. (2018). Density of wood of pine and spruce in the postagrogenic soil of the boreal zone. In Proceedings of the $24^{\text {th }}$ Annual International Scientific Conference 'Research for Rural Development 2018' 16-18 May Jelgava, Latvia. Forestry and wood processing Vol. 1, 92-96. DOI: 10.22616/rrd.24.2018.014.

10. Lohov, D.V. (2011). Лесоводственная оценка и показатели качества древесины культур сосны на залежных землях (Forestry assessment of the pine wood quality in silvicultures on the postagrogenic lands). Ecological problems of the North: collection of scientific papers. 14, 73-76. (in Russian)

11. Lyury, D.I., Goryachkin, S.V., \& Karavaeva, N.A. (2010). Динамика сельскохозяйственных земель России в XX веке и постагрогенное восстановление растительности и почв (The dynamics of agricultural lands in Russia in the $20^{\text {th }}$ century and the postagrogenic restoration of vegetation and soils). Moscow: GVOS, 416 p. (in Russian)

12. Polubojarinov, O.I. (1976). Плотность древесины (Wood density). Moscow: Forest industry, 159 p. (in Russian)

13. Ramankutty, N., \& Foley, J.A. (1999). Estimating historical changes in land cover: North American croplands from 1850 to 1992. Global Ecology and Biogeography. 8, 381-396.

14. Ruskule, A., Nikodemus, O., Kasparinska, Z., Kasparinskis, R., \& Brūmelis, G. (2012). Patterns of afforestation on abandoned agriculture land in Latvia. Agroforestry Systems, 85, 215-231.

15. Romanenko, G.A. (2008). Агроэкологическое состояние и перспективы использования земель России, выбывших из активного сельскохозяйственного оборота (Agroecological state and prospects for the use of land withdrawn from active agricultural use). Moscow: Federal State 'Rosinformagroteh', 64 p. (in Russian)

16. Tomczak, A., \& Jelonek, T. (2013). Radial variation in the wood properties of Scots pine (Pinus sylvestris L.) grown on former agricultural soil. For. Res. Pap. 74, 171-177. 
17. Zeidler, A., Vlastimil, B., \& Schenfelder, O. (2018). Comparison of wood quality of Douglas-fir and spruce from afforested agricultural land and permanent forest-land in the Czech Republic. Forests 9, 13

18. Zeltiňš, P., Katrevičs, J., Gailis, A., Maaten, T., Bāders, E., \& Jansons, Ā. (2018). Effect of Stem Diameter, Genetics, and Wood Properties on Stem Cracking in Norway Spruce. Forests, 9, 546. 